\title{
MEDICINAL VALUE OF LAGERSTROEMIA SPECIOSA: AN UPDATED REVIEW
}

\author{
ALI ESMAIL AL-SNAFI \\ Department of Pharmacology, College of Medicine, Thiqar University, Iraq \\ Email: aboahmad61@yahoo.com
}

Received: 13 May 2019, Revised and Accepted: 14 Jul 2019

\begin{abstract}
Lagerstroemia speciosa (Family: Lythraceae) is native to Asia-tropical and subtropical regions. The phytochemical investigation of Lagerstroemia speciosa leaf and fruit revealed that it contained steroids, terpenoids, glycosides, phenolic compounds, $\alpha$-amino acids, saponins, starch, alkaloids, carbohydrates, organic acids, flavonoids, reducing sugars, tannins and many other active metabolites. Lagerstroemia speciosa possessed many Pharmacological effects included antimicrobial, antioxidant, anticancer, antidiabetic, hypolipidemic, antiobesity, anti-inflammatory, analgesic, gastrointestinal, diuretic, thrombolytic, cardiovascular, central nervous, inhibition of TNF $\alpha$ production, xanthine oxidase inhibitition, hepatoprotective and nephroprotective effects. The current review discussed the chemical constituents, pharmacological and therapeutic effects of Lagerstroemia speciosa
\end{abstract}

Keywords: Constituents, Pharmacology, Lagerstroemia speciosa

(c) 2019 The Authors. Published by Innovare Academic Sciences Pvt Ltd. This is an open access article under the CC BY license (http://creativecommons.org/licenses/by/4.0/] DOI: http://dx.doi.org/10.22159/ijcpr.2019v11i5.35708

\section{INTRODUCTION}

Plants are a valuable source of a wide range of secondary metabolites, which are used as pharmaceuticals, agrochemicals, flavours, fragrances, colours, biopesticides and food additives. Recent reviews revealed that the medicinal plants possessed antimicrobial [1-3], antiparasitic [1], central nervous [2-4], cardio-vascular [1,4-5], antioxidant [5], reproductive [1-3], gastro-intestinal [1-5], respiratory [2], antidiabetic [2], dermatological [5], anticancer [2, 4-5], antiinflammatory, antipyretic and analgesic [2, 3], immunological [2, 5-6], hepato and reno-protective [3-5] and many other pharmacological effects. Lagerstroemia speciosa (Family: Lythraceae) is native to Asiatropical and subtropical regions. The phytochemical investigation of Lagerstroemia speciosa leaf and fruit revealed that it contained steroids, terpenoids, glycosides, phenolic compounds, $\alpha$-amino acids, saponins, starch, alkaloids, carbohydrates, organic acids, flavonoids, reducing sugars, tannins and many other active metabolites. Lagerstroemia speciosa possessed many Pharmacological effects included antimicrobial, antioxidant, anticancer, antidiabetic, hypolipidemic, antiobesity, anti-inflammatory, analgesic, gastrointestinal, diuretic, thrombolytic, cardiovascular, central nervous, inhibition of TNF $\alpha$ production, xanthine oxidase inhibitition, hepatoprotective and nephroprotective effects. The current review will highlight the chemical constituents, pharmacological and therapeutic effects of Lagerstroemia speciosa.

\section{Plant profile}

\section{Synonyms}

Adambea glabra, Lagerstroemia augusta, Lagerstroemia flos-reginae, Lagerstroemia macrocarpa, Lagerstroemia major, Lagerstroemia munchausia, Lagerstroemia plicifolia, Lagerstroemia reginae, Munchausia speciosa [7].

\section{Taxonomic classification}

Kingdom: Plantae; Subkingdom: Viridiplantae; Infrakingdom: Streptophyta; Superdivision: Embryophyta; Division: Tracheophyta; Subdivision: Spermatophytina; Class: Magnoliopsida; Superorder: Rosanae; Order: Myrtales; Family: Lythraceae; Genus: Lagerstroemia; Species: Lagerstroemia speciosa [8].

\section{Common names}

Arabi: Zahar kahwa katheb, ward al-kahwa, lailak hindi, henna hindi, berangik; Brazil: resedá-flor-da-rainha, resedá-gigante; Burmese: Gawkng-uchyamang; Chinese: Bai ri hong, Da hua zi wei; English:
Banaba, Pride of India, queen's crape-myrtle, queen of flowers; Hindu: Jarul, Arjuna, Bondaro, Challa, Ajhar, Varagogu, Motobhandaro; Indonesia: Bungur, Bungur tekuyung, Ketangi; Thailand: Chuang-muu, Tabaek dam, Inthanin nam $[8,9]$.

\section{Distribution}

It was native to Asia-tropical and subtropical regions: India, Sri Lanka, Cambodia, Myanmar, Thailand, Vietnam, Indonesia, Malaysia, Philippines, Bangladesh Japan, and it was widely cultivated [9-11].

\section{Description}

Lagerstroemia speciosa is a medium-large-sized evergreen tree grows up to $25 \mathrm{~m}$ high. The leaves are opposite, leathery, oblong to ovate in shape, glaborus with short petiole, and measures $10-20 \mathrm{~cm} \times 5-7.5 \mathrm{~cm}$. The flowers are in large terminal panicle, regular in shape, varying from pink to purple in color, measure $5.0-7.5 \mathrm{~cm}$ wide. The calyx is in green ribbed tube with 6 leathery sepal lobes and 6 lilac purple petals with wavy margins up to $3.5 \mathrm{~cm}$ long, attached between the sepals by short claws. The stamens are numerous, with purple filaments and golden yellow anthers. The pistil is simple with a long purple style of up to $5 \mathrm{~cm}$ long, a dark green stigma and a superior ovary. The fruit is hard woody, subglobose, measures about $2.5 \mathrm{~cm}$ long. The seeds are winged $[12,13]$.

\section{Traditional uses}

The roots were used as astringent, stimulant and febrifuge, it was also used for stomach problems. Tea of the leaves was used in the treatment of diabetes mellitus and for weight loss. The leaves, flowers and barks were used as purgative. Leaf decoction or infusion was used for bladder and kidney inflammation, dysuria and other urinary dysfunctions, for cholesterol deduction, hypertension and diabetes. Poultice of the leaves was used as remedy for malaria, headache and cracked heeling by application over the lesions. Decoction of the bark was used for gastrointestinal tract disturbance, stomachache, haematuria and depression. The seeds were used as narcotic [9, 14-16].

\section{Parts used}

The roots, leaves and barks $[9,17]$.

\section{Physiochemical characteristics}

The physicochemical investigation of Lagerstroemia speciosa leaves showed the following values: loss on drying 8.2141 \pm 0.9300 , 
moisture content $7.8593 \pm 0.8141$, total ash content $7.4725 \pm 0.7277$ and acid-insoluble ash content $1.2176 \pm 0.6223 \%$ of the dry weight. Ethanol-, dichloromethane-and water extractive values were $9.0280 \pm 2.2937,2.9442 \pm 0.8827$ and $13.1895 \pm 1.9934 \%$ of the dry weight, respectively [18]. The moisture content of fruit was $14.77 \%$, and the total ash contents was $4.42 \%$ [19].

\section{Chemical constituents}

The preliminary phytochemical investigation of Lagerstroemia speciosa leaf and fruit showed that they contained steroids, terpenoids, glycosides, phenolic compounds, $\alpha$-amino acids, saponins, starch, alkaloids, carbohydrates, organic acids, flavonoids, reducing sugars and tannins [18-19, 21-23].

The fat content for leaf and fruit was $3.36 \%$ and $0.26 \%$. The fiber content was $13.76 \%$, protein contents was $11.24 \%$, and carbohydrate contents was $51.20 \%$ for Lagerstroemia speciosa leaf. The fiber, protein and carbohydrate contents for Lagerstroemia speciosa fruit were $35.39 \%, 2.88 \%$ and $42.28 \%$, respectively. The relative abundance of minerals in Lagerstroemia speciosa leaf was $0.456 \%$ for $\mathrm{Ca}, 0.443 \%$ for $\mathrm{K}, 0.206 \%$ for $\mathrm{S}$ and $0.017 \%$ for $\mathrm{Mn}$. The relative abundance of minerals in Lagerstroemia speciosa fruit was 60.848\% for $\mathrm{K}, 25.717 \%$ for $\mathrm{Ca}, 5.561 \%$ for $\mathrm{P}, 3.477 \%$ for $\mathrm{S}, 2.733 \%$ for $\mathrm{Fe}$, $0.517 \%$ for $\mathrm{Zn}, 0.491 \%$ for $\mathrm{Rb}, 0.418 \%$ for $\mathrm{Cu}$ and $0.238 \%$ for $\mathrm{Sr}[19]$.

Heavy metals analysis of the Lagerstroemia speciosa leaf extracts showed that they contained mercury $0.626 \mathrm{ppm}$, arsenic $2.02 \mathrm{ppm}$, lead $1.16 \mathrm{ppm}$ and cadmium $0.26 \mathrm{ppm}$, the levels of all the studied heavy metals were below the recommended concentrations [22]. $p$ Coumaric acid, kaempferol, quercetin, and isoquercitrin, were isolated from the roots. Six pentacyclic triterpene acids (oleanolic, arjunolic, asiatic, maslinic, corosolic and 23-hydroxyursolic acids) were isolated from the leaves [24].

Significant variation in percentage distribution of corosolic acid ranging from $0.005 \%$ to $0.868 \%$ dry weight were recorded in 12 natural populations across the Southern Western Ghats of India [25].

Many phenolics included ellagic acid, epicatechin gallate, quercetin, phenolic glucosides [1-0-benzyl-6-0-E-caffeoyl- $\beta$-d-glucopyranoside and $\quad 1-0-(7 \mathrm{~S}, \quad 8 \mathrm{R})$-guaiacylglycerol-(6-0-E-caffeoyl)- $\beta$-d-glucopyranoside] were isolated from the aerial parts of Lagerstroemia speciosa $[26,27]$.

Total phenol, total flavonoid and tannin contents determined in the $40 \%$ methanolic extract of dried leaves of Lagerstroemia speciosa were $159.93 \pm 0.87$ of $\mathrm{GAE}$ in $\mu \mathrm{g} / \mathrm{mg}, 9.37 \pm 0.73 \mathrm{QE}$ in $\mu \mathrm{g} / \mathrm{mg}$ and $80.5 \pm 0.19 \mathrm{GAE}$ in $\mu \mathrm{g} / \mathrm{mg}$ respectively [28].

31-Norlargerenol acetate, 24-methylenecycloartanol acetate, its 31nor analog, largerenol acetate, tinotufolins $\mathrm{C}$ and $\mathrm{D}$, lutein, phytol, sitosterol and sitosterol acetate were isolated from the leaves of Lagerstroemia speciosa [29].

Ellagitannins [(flosin A and B; reginin A, B, C and D, and lagerstannins A, B, C); Lagerstroemin; stachyurin; casuarinin; casuariin; epipunicacortein A; 2, 3-(S)-hexahydroxydiphenoylalpha/beta-D-glucose], lageracetal, lasubine I and lasubine II, 3-0methyl-ellagic acid 4'-sulfate, ellagic acid, four methyl ellagic acid derivatives (3-0-methylellagic acid, 3,3'-di-0-methylellagic acid, 3,4,3'-tri-0-methylellagic acid, and 3,4,8,9,10-pentahydroxydibenzo[b,d]pyran-6-one), corosolic acid, gallic acid, 4hydroxybenzoic acid, 3-0-methylprotocatechuic acid, caffeic acid, pcoumaric acid, kaempferol, quercetin, isoquercitrin, campesterol, stigmasterol, maslinic acid and pterocarinin were isolated from Lagerstroemia speciosa [29-36].

Triterpenoid (3beta, 23-dihydroxy-1-oxo-olean-12-en-28-oic acid) was isolated from the leaves of Lagerstroemia speciosa [37]. Keto fatty acid (9-ketooctadec-cis-11-enoic acid), nonanedioic acid, 12acetyloxy-9-octadecenoic acid, and 16-methyl-heptadecandic acids were isolated from Lagerstroemia speciosa seeds [38, 39].

The essential oils of the fruits of Largerstroemia speciosa contained mostly hydrocarbons: Methylcyclohexane (60.9\%), methylbenzene (18.2\%), o-xylene (3.04\%) representing $82.14 \%$ of the total essential oil [40].
Lagerstroemia speciosa flower oil contained: $\alpha$-pinene (10.38\%), $\beta$ pinene, (8.45\%) myrcene (6.76\%), limonene (2.6\%), $\alpha$-bisabolol $(3.14 \%)$ as major components. However, the components identified from the essential oil and their percentages were: $\alpha$-pinene 10.38, $\beta$ pinene 8.45, myrcene 6.76, limonene 2.60, Cis- $\beta$-ocimene 1.33 , trans- $\beta$ ocimene 2.12 , linalool 1.22 , terpinolene 0.16 , 8-hydroxy linalool 1.12, $\alpha$ terpineol 12.76, Benzene acetaldehyde trac,borneol 2.18, p-cymen-8-ol 0.70 , cis-dihydrocarvone 1.23 , trans-dihydrocarvone $1.7, \alpha$-copaene 1.14 , $\gamma$-Elemene 0.38, humulene 0.89, a $\beta$-bisabolene 5.97, $\gamma$-cadinene trac, $\beta$ selinene $3.54, \delta$-cadinene 2.47 , caryophyllene oxide 1.69 , Humulene oxide 0.79 , $\alpha$-bisabolol 3.14 and Nootkatone $1.90 \%$ [41].

\section{Pharmacological effects}

\section{Antimicrobial effects}

Seed extracts were tested for antibacterial effect against different bacterial organisms, some fractions of seed extracts of Lagerstroemia speciosa showed high antibacterial activity when tested against both Gram-positive and Gram-negative bacteria [42].

The methanolic extracts of Lagerstroemia speciosa leaves and barks were evaluated for their antimicrobial activity against 11 Grampositive, Gram-negative bacteria and 3 fungi using disk diffusion technique. The average zone of inhibition exhibited by methanolic leaves and barks extracts $(500 \mu \mathrm{g} / \mathrm{disc})$ was $10-20 \mathrm{~mm}$ and $12-21$ $\mathrm{mm}$ respectively [43]. The Lagerstroemia speciosa leaf extracts were investigated for antibacterial and antibiofilm activities against potential clinical strains (Staphylococcus aureus, Escherichia coli, P. aeruginosa and Salmonella typhi) by well diffusion technique. The antibacterial property was also investigated against common food borne pathogens (Listeria monocytogenes and Bacillus cereus) at varied concentration 250 to $1000 \mu \mathrm{g} / \mathrm{ml}$. The antibiofilm assay was carried out from 250 to $1000 \mu \mathrm{g} / \mathrm{ml}$ against $P$. aeruginosa by cover slip technique. Only minimum inhibition was seen in alcoholic extract for antibacterial activity, whereas all other extracts showed negligible activity. $P$. aeruginosa biofilm inhibited to $93.0 \pm 2 \%$ and $91 \pm 2 \%$ at higher concentration $(1000 \mu \mathrm{g} / \mathrm{ml})$ by methanolic and ethanolic extract respectively [44].

Antibacterial activity of ethanol and water extracts of leaves of Lagerstroemia speciosa were tested by plate agar diffusion method against Gram positive and Gram negative bacteria. The MIC of ethanol and water extracts of leaves against Staphylococcus aureus: 14 and 15, Bacillus subsilis: 12 and 15, Pseudomonas aeruginosa: 14 and 17, and Escherichia coli: 16 and $17 \mathrm{~mm}$ respectively. Water extract being the most effective [45].

The antimicrobial effect of the flowers extracts of Lagerstroemia speciosa was studied against Gram positive bacteria (Bacillus cereus, Bacillus megaterium, Bacillus subtilis, Staphylococcus aureus, Micrococcus luteus), Gram negative bacteria (Escherichia coli, Pseudomonas aeruginosa, Salmonella paratyphi, Salmonella typhi, Shigella boydii, Shigella dysenteriae, Vibrio mimicus, Vibrio parahemolyticus) and Fungi (Saccharomyces cerevisiae, Aspergillus niger). Methanolic crude extract possessed antimicrobial effect against all the tested microorganisms. The largest zone of inhibition (19 $\mathrm{mm}$ ) was observed for the carbon tetrachloride soluble fraction against Staphylococcus aureus [46].

The antibacterial effect of the methanolic extract of Lagerstroemia speciosa leaves was investigated against Escherichia coli, Salmonella typhimurium, Staphylococcus aureus and Pseudomonas aeruginosa. The extract possessed high antibacterial activity against Escherichia coli (15 $\mathrm{mm})$, Staphylococcus aureus $(10 \mathrm{~mm})$, Pseudomonas aeruginosa $(10$ $\mathrm{mm}$ ), but had no activity against Salmonella typhimurium [47].

Lagerstroemia speciosa bark extract was investigated for its antimicrobial effects by using the time-kill curves assay. The extract showed a concentration-dependent killing effect for both $B$. spizizenii ATCC 6633 and A. anitratus. The number of bacteria was significantly reduced when they were exposed to 2MIC level. $B$. spizizenii ATCC 6633 was more susceptible to the extract as compared to A. anitratus [48].

The various extracts of the fruits of Lagerstroemia speciosa (50, 100 and $150 \mu \mathrm{g} / \mathrm{ml}$ ) were screened for antimicrobial activity by paper 
disc diffusion method. Most of the extracts were active against all the tested bacteria, MIC value against $S$. aureus was $(15-39 \mu \mathrm{g} / \mathrm{ml}), E$. coli $(16-38 \mu \mathrm{g} / \mathrm{ml})$, P. aeruginosa $(15-39 \mu \mathrm{g} / \mathrm{ml})$ and B. subtilis (14$39 \mu \mathrm{g} / \mathrm{ml}$ ), the extracts were also active against all the tested fungi, MIC value against $A$. niger was $(16-38 \mu \mathrm{g} / \mathrm{ml})$, A. flavus $(18-39$ $\mu \mathrm{g} / \mathrm{ml}$ ) and C. albicans (16-38 $\mu \mathrm{g} / \mathrm{ml}$ ) [23].

The ability of Lagerstroemia speciosa fruit extract to antagonize cellto-cell communication, expression of virulence genes and factors, and biofilm formation was evaluated in Pseudomonas aeruginosa strain PA01. The results revealed that Lagerstroemia speciosa fruit extract caused down regulation of quorum sensing-related genes (las and $\mathrm{rhl}$ ) and their respective signalling molecules, $\mathrm{N}$ acylhomoserine lactones, without affecting the growth of $P$. aeruginosa PA01. Significant inhibition of virulence factors: Las A protease, Las B elastase, and pyoverdin production, were also recorded. Application of extract to P. aeruginosa PA01 biofilms increased $P$. aeruginosa susceptibility to tobramycin [49].

The anti-human rhinovirus activity of orobol 7-0-d-glucoside isolated from Lagerstroemia speciosa was evaluated in Hela cells using a cytopathic effect reduction method. Orobol 7-0-d-glucoside showed a broad-spectrum anti-human rhinovirus activity with $\mathrm{IC}_{50}$ ranging from 0.58 to $8.80 \mathrm{microg} / \mathrm{ml}$. The $\mathrm{CC}_{50}$ of orobol $7-0-\mathrm{d}-$ glucoside was more than $100 \mathrm{microg} / \mathrm{ml}$ [50].

The antiviral activity of quercetin 7-glucoside isolated from Lagerstroemia speciosa was investigated against human rhinovirus 2 (HRV2) using a cytopathic effect reduction method. Quercetin 7glucoside showed strong anti-HRV2 activity by reducing the formation of cytopathic effect. Quercetin 7-glucoside also inhibited virus replication in the initial stage of virus infection by indirect interaction with virus particles [51].

Aqueous and 50 percent ethanolic extracts of the leaves and stems of Lagerstroemia speciosa were evaluated for anti-HIV activity using in vitro reporter gene-based assays. All the extracts showed a dosedependent inhibition of HIV-1-infection in TZM-bl and CEM-GFP cell lines, with IC 50 of 1 to $25 \mu \mathrm{g} / \mathrm{ml}$ [52].

The antiviral activities and possible mode of action of the tannin ellagic acid from the leaves of Lagerstroemia speciosa against HRV$2,-3$, and- 4 , were studied. As judged by $50 \%$ inhibitory concentration values, natural ellagic acid was $1.8,2.3$, and 2.2 times more toxic toward HRV-2 (38 $\mu \mathrm{g} / \mathrm{ml}), \mathrm{HRV}-3(31 \mu \mathrm{g} / \mathrm{ml})$, and HRV-4 $(29 \mu \mathrm{g} / \mathrm{ml})$ than ribavirin, respectively. The inhibition rate of preincubation with $50 \mu \mathrm{g} / \mathrm{ml}$ ellagic acid was $17 \%$, whereas the continuous presence of ellagic acid during infection led to a significant increase in the inhibition (70\%). Treatment with $50 \mu \mathrm{g} / \mathrm{ml}$ ellagic acid considerably suppressed HRV-4 infection only when added just after the virus inoculation $(0 \mathrm{~h})(87 \%$ inhibition), but not before- $1 \mathrm{~h}$ or after $1 \mathrm{~h}$ or later $(<20 \%$ inhibition) [53].

\section{Antioxidant activity}

The hydroalcoholic extract of leaves of Lagerstroemia speciosa was studied for antioxidant activity using many methods. The hydroalcoholic extract of leaves of Lagerstroemia speciosa showed the dose-dependent free radical scavenging property. $\mathrm{IC}_{50}$ value was $4.75 \pm 0.25 \mu \mathrm{g} / \mathrm{ml}$ in DPPH method, which was comparable to that of ascorbic acid and rutin. While, $\mathrm{IC}_{50}$ value was $28.00 \pm 0.16 \mu \mathrm{g} / \mathrm{ml}$ in hydrogen peroxide method, and $750 \pm 3.66 \mu \mathrm{g} / \mathrm{ml}$ in nitric oxide model [54].

The methanolic extracts of Lagerstroemia speciosa leaves and barks were evaluated for their antioxidant activity using DPPH scavenging activity, for total antioxidant capacity, reducing ability as well as total phenolic contents. IC ${ }_{50}$ values were $27.89 \pm 0.83 \mu \mathrm{g} / \mathrm{ml}, 21 \pm 0.61$ $\mu \mathrm{g} / \mathrm{ml}$ and $16.76 \pm 1.11 \mu \mathrm{g} / \mathrm{ml}$ for methanolic leaves and barks extracts and standard ascorbic acid, respectively. Reducing ability was found concentration-dependent for both the extracts. The total phenolic content was $71.06 \pm 2.01$ and $60.65 \pm 2.16 \mathrm{mg} / \mathrm{g}$ equivalent of gallic acid for methanolic leaves and barks extracts, respectively.

The in vitro antioxidant activity of Lagerstroemia speciosa leaves (ethyl acetate, ethanol, methanol and water extracts) was studied by examining their superoxide, hydroxyl ion scavenging and by measuring lipid peroxidation. The ethyl acetate and ethanol extracts possessed the greater antioxidant property than the methanol and water extracts [55].

The ability of the Lagerstroemia speciosa $40 \%$ methanolic extract to mitigate oxidative stress was demonstrated by hydrogen peroxide $\left(\mathrm{H}_{2} \mathrm{O}_{2}\right)$ induced oxidative stress in $3 \mathrm{~T} 3-\mathrm{L} 1$ cells. the $\mathrm{IC}_{50}$ value of Lagerstroemia speciosa extract was $20.43 \mu \mathrm{g} / \mathrm{ml}$, and that of ascorbic acid which used as positive control was $49.64 \mu \mathrm{g} / \mathrm{ml}$ [28].

The hot water extracts of Lagerstroemia speciosa leaves showed strong antioxidative activity in a linoleic acid autoxidation system. The extract also possessed potent radical scavenging action on 1,1diphenyl-2-picrylhydrazyl (DPPH) radicals and superoxide radicals $\left(\mathrm{O}^{2-}\right)$ ) generated by a hypoxanthine (HPX)/xanthine oxidase system. In vitro lipid peroxidation of rat liver homogenate induced by tertbutyl hydroperoxide was also inhibited by the addition of the extract in a dose-dependent manner [56].

The antioxidant activity of the $95 \%$ ethanol and water extracts $(0.625,1.25,2.5,5,10$, and $20 \mu \mathrm{g} / \mathrm{ml})$ of Lagerstroemia speciosa leaf was studied by DPPH free radical scavenging assay method. IC 50 values were found to be 2.6 and $6.2 \mu \mathrm{g} / \mathrm{ml}$ for ethanol extracts and 4.3 and $9.2 \mu \mathrm{g} / \mathrm{ml}$ for aqueous extract of leaf and fruit samples, respectively [19].

The chloroform soluble fraction of Lagerstroemia speciosa extract demonstrated the highest antioxidant activity ( IC $_{50}=4.20 \pm 0.41 \mu \mathrm{g} / \mathrm{ml}$ ) by (DPPH) [46].

The protective effects of hot water extracts from Lagerstroemia speciosa leaves were studied in SIN-1-induced oxidative stress in HIT-T15 cells, the cellular levels of ROS, lipid peroxidation and endogenous antioxidant enzymes, including superoxide dismutase, catalase and glutathione peroxidase were investigated. The extract decreased the intracellular levels of ROS and lipid peroxidation, and increased the activities of antioxidant enzymes. The extract possessed a cytoprotective effect against SIN-1-induced oxidative stress in HIT-T15 cells through the inhibition of lipid peroxidation, a decrease in ROS levels and an increase in antioxidant enzyme activity [57].

\section{Anticancer effects}

The cytotoxicity of the Lagerstroemia speciosa flower essential oils was studied using Dalton's Lymphoma Ascites cells (DLA) and Ehrlich Ascites Carcinoma cells (EAC). Lagerstroemia speciosa flower essential oils at a concentration of $50 \mu \mathrm{l} / \mathrm{ml}$ produced $13.33 \%$ and $31 \%$ cytotoxicity to DLA and EAC cells, respectively [41].

The essential oils of the fruits of Largerstroemia speciosa possessed cytotoxicity with $\mathrm{IC}_{50}$ value of $1.701 \mu \mathrm{g} / \mathrm{ml}$ in brine shrimp toxicity assay [40].

The anticancer activity of corosolic acid isolated from Lagerstroemia speciosa on cell viability and apoptosis was investigated in HCT116 human colon cancer cells. Corosolic acid was dose-dependently inhibited the viability of HCT116 cells. The features of apoptosis, such as chromatin condensation, a sub-G1 peak and phosphatidylserine externalization were apparent following treatment with corosolic acid. The apoptotic cell death induced by corosolic acid was accompanied by the activation of caspase-8,-9 and-3, which was completely abrogated by the pancaspase inhibitor, z-VAD-FMK. In addition, corosolic acid upregulated the levels of pro-apoptotic proteins, such as Bax, Fas and FasL and down-regulated the levels of anti-apoptotic proteins, such as Bcl-2 and surviving [58].

Quercetin, a flavonoid isolated from the leaves of Lagerstroemia speciosa showed significant in vitro cytotoxicity against MCF-7 cell lines at $500 \mu \mathrm{g} / \mathrm{ml}$ when compared to the crude extract [59].

The cytotoxic effects of $40 \%$ methanolic extract of dried leaves of Lagerstroemia speciosa, an aqueous extract of Allium sativum and their combination in the ratio of 1:2, 1:1 w/w were evaluated using 3T3 L1 preadipocyte cells. The $\mathrm{IC}_{50}$ value of the $40 \%$ methanolic extract of dried leaves of Lagerstroemia speciosa was $323.6 \mu \mathrm{g} / \mathrm{ml}$. When the extract of the leaves of Lagerstroemia speciosa mixed with aqueous 
extract of Allium sativum, they possessed more cytotoxic effects, while, $1: 1 \mathrm{w} / \mathrm{w}$ mixture suppressed the differentiation of preadipocytes to adipocytes without exerting significant cytotoxic effects [28].

The ethanol extract of the dried fruits of Lagerstroemia speciosa was investigated for cytotoxic activity. The extract produced a prominent cytotoxic activity against brine shrimp Artemia salina with $\left(\mathrm{LC}_{50}=60\right.$ $\mu \mathrm{g} / \mathrm{ml}$ and $\mathrm{LC}_{90}$

The brine shrimp lethality test was carried out to determine the toxic level of the Lagerstroemia speciosa bark extract towards the eukaryotic cells. The extract was found to be nontoxic during the short term (acute) exposure but it was toxic during the prolonged time (chronic) exposure. The $\mathrm{LC}_{50}$ for the acute and chronic test were 3422.68 and $35.30 \mu \mathrm{g} / \mathrm{ml}$, respectively [48].

The cytotoxic potential of the flowers of Lagerstroemia speciosa extracts was examined by brine shrimp lethality bioassay. The most prominent cytotoxic potency was showed by hexane soluble fraction $\left(\mathrm{LC}_{50}=2.00 \pm 0.31 \mu \mathrm{g} / \mathrm{ml}\right)[46]$.

The methanolic extracts of Lagerstroemia speciosa leaves and barks were evaluated for their cytotoxic effect using brine shrimp lethality bioassay. $\mathrm{LC}_{50}$ value of methanolic leaves extract was $(9.602 \mu \mathrm{g} / \mathrm{ml})$, comparing with $\mathrm{LC}_{50}$ of vincristine sulphate as a positive control $(6.25 \mu \mathrm{g} / \mathrm{ml})$ [43].

\section{Antidiabetic, hypolipidemic and antiobesity effects}

The ellagitannin (lagerstroemin) was identified as an effective component of the Lagerstroemia speciosa extract responsible for antidiabetic activity. In a different approach, using 3T3-L1 adipocytes as a cell model and a glucose uptake assay as the functional screening method, water extract exhibited an insulin-like glucose transport inducing activity. With the coupling of HPLC fractionation and a glucose uptake assay, gallotannins were identified in the extract as components responsible for the activity. Penta-O-galloyl-glucopyranose (PGG) was identified as the most potent gallotannin. PGG possessed significantly higher glucose transport stimulatory activity than lagerstroemin. PGG also exhibited anti-adipogenic properties in addition to stimulating the glucose uptake in adipocytes [61].

The hypoglycemic effect of the flowers of Lagerstroemia speciosa extract was studied in mice. The extract ( $400 \mathrm{mg} / \mathrm{kg}$ dose) reduced blood sugar level by $56.12 \%$ after three hours of administration of glucose solution [46]

The antidiabetic activity of the leaves extract of Lagerstroemia speciosa [standardized to 1\% corosolic acid (Glucosol)] was studied in a randomized clinical trial in Type II diabetics. Glucosol at daily dosages of 32 and $48 \mathrm{mg}$ for $2 \mathrm{w}$ induced a significant reduction in the blood glucose levels. Glucosol in a soft gel capsule formulation showed a $30 \%$ decrease in blood glucose levels compared to a $20 \%$ drop in hard gelatin capsule formulation $(\mathrm{P}<0.001)$, suggesting that the soft gel formulation has better bioavailability than a dry-powder formulation [62].

The antidiabetic effect of the aqueous leaf extract of Lagerstroemia speciosa was studied in streptozotocin-induced diabetic mice. The extract was effectively decreased the blood glucose after $15^{\text {th }}$ day. The extract also inhibited lipid peroxidation, and at a dose of 150 $\mathrm{mg} / \mathrm{kg}$ bw, it reduced streptozotocin generated reactive intermediates and radical species helping to regulate normal levels of antioxidative markers like superoxide dismutase, catalase, glutathione-S-transferase and reduced glutathione. Aqueous leaf extract of Lagerstroemia speciosa $(150 \mathrm{mg} / \mathrm{kg}$ bw) effectively decreased the blood glucose in streptozotocin-induced diabetic mice after $15^{\text {th }}$ day of treatment. The leaf extract potentially inhibited lipid peroxidation and effectively intercept/neutralize reactive oxygen species such as superoxide, $\mathrm{H}_{2} \mathrm{O}_{2}$ and $\mathrm{NO}$ based free radicals [63].

The hypoglycemic effect of Lagerstroemia speciosa leaves extract (500, 1000 and $2000 \mathrm{mg} / \mathrm{kg}$ ) was studied in normal and streptozotocininduced diabetic rats. A significant $(\mathrm{p}<0.05)$ decrease in fasting blood glucose level was observed in diabetic rats received the extract at the doses of 1000 and $2000 \mathrm{mg} / \mathrm{kg}$ on the $5^{\text {th }}$ and $12^{\text {th }}$ days of administration compared to the control diabetic group. In an oral glucose tolerance test, none of the doses of the extract showed any effects on blood glucose level in either diabetic or normal rats [64].

The hypoglycemic effects of Lagerstroemia speciosa was studied in alloxan-induced diabetes in ICR strain of mice. Spray-dried Lagerstroemia speciosa powder $(1000 \mathrm{mg} / \mathrm{kg})$ or decoction (20 $\mathrm{ml} / \mathrm{kg}$ ) was administered to mice for $28 \mathrm{~d}$ by gavage. Spray dried Lagerstroemia speciosa powder and decoction significantly reduced blood $(\mathrm{p}<0.01)$, urinary glucose $(\mathrm{p}<0.05)$ levels, and body weight $(p<0.05)$ of diabetic mice from day 8 to 28 compared with the diabetic control. The food intake of diabetic mice was higher $(\mathrm{P}<0.05)$ compared with non-diabetic control and Lagerstroemia speciosa-treated diabetic mice from day 22 to 28 . The fluid intake was lower $(\mathrm{p}<0.01)$ in non-diabetic mice and Lagerstroemia speciosa-treated diabetic mice from day 8 to 28 compared with the diabetic mice [65].

Diet containing $5 \%$ of the hot-water Lagerstroemia speciosa leaves, fed to hereditary diabetic mice (Type II) for $5 \mathrm{w}$, significantly decreased blood plasma glucose level and significantly lowered serum insulin, total cholesterol level, and the amount of urinary excreted glucose [66].

The potential antidiabetic activity of ethyl acetate extract of the leaves of Lagerstroemia speciosa was investigated by alpha-amylase and alpha-glucosidase inhibition assay. Six pentacyclic triterpenes (oleanolic acid, arjunolic acid, asiatic acid, maslinic acid, corosolic acid and 23-hydroxyursolic acid) isolated from the leaves of Lagerstroemia speciosa exhibited no or weak inhibitory activity against alphaamylase and middle alpha-glucosidase inhibitory activities. Corosolic acid, showed the highest activity against alpha-glucosidase $\left(\mathrm{IC}_{50}=3.53\right.$ microg/ml) [24]. The results of in vitro $\alpha$-glucosidase inhibitory assay showed that the $\mathrm{IC}_{50}$ value of the $40 \%$ methanolic leaves extract of Lagerstroemia speciosa was $0.3 \mu \mathrm{g} / \mathrm{ml}$ [28].

Some ellagitannins isolated from the leaves of Lagerstroemia speciosa exhibited strong activities in both stimulating insulin-like glucose uptake and inhibiting adipocyte differentiation in 3T3-L1 cells. Meanwhile, ellagic acid derivatives showed an inhibitory effect on glucose transport assay [30].

Ellagitannins, lagerstroemin, flosin B and reginin A, isolated from the aqueous acetone extract of the leaves of Lagerstroemia speciosa increased glucose uptake of rat adipocytes, and could be responsible for lowering of blood glucose level [67].

Corosolic acid, isolated from the methanol extract of Lagerstroemia speciosa possessed antidiabetic activity. However, different cell model led to the discovery of other compounds. The ellagitannin, lagerstroemin was identified as an effective component of Lagerstroemia speciosa extract responsible for antidiabetic activity [61]. A randomized, double-blind, placebo-controlled clinical trial was carried out in 24 patients with metabolic syndrome. 12 patients received Lagerstroemia speciosa, $500 \mathrm{mg}$ twice daily before meals during $3 \mathrm{mo}$, and 12 patients received placebo with the same prescription and for the same period. Area under the curve of glucose and insulin, total insulin secretion (insulinogenic index), first-phase of insulin secretion (Stumvoll index) and insulin sensitivity (Matsuda index) were determined. Lagerstroemia speciosa has shown evidence of beneficial modification of the metabolic syndrome, insulin sensitivity and insulin secretion [68].

The neuroprotective effects of alcoholic extract of Lagerstroemia speciosa (50 and po, for $58 \mathrm{~d}$ ) was investigated in painful diabetic neuropathy in streptozotocin-induced diabetic neuropathy in rats. Lipid peroxidation, reduced glutathione and nitric oxide content in sciatic nerve were evaluated. The extract significantly restored the reduced body weight and the elevated blood sugar level. The extract also showed dose-dependent reduction in pain threshold tested by mechanical, cold and thermal hyperalgesia. The extract also showed antioxidant effects [69].

Low doses of Lagerstroemia speciosa extracts inhibited the interactions between nuclear factors and target DNA elements mimicking sequences recognized by the nuclear factor kappaB (NFkappaB). Aqueous extracts of the leaves of Lagerstroemia speciosa completely blocked the activation of NF-kappaB by tumor necrosis 
factor (TNF) in rat cardiomyocyte $\mathrm{H} 9 \mathrm{c} 2$ cells in a dose and timedependent manner. Diabetes leads to cardiomyocyte hypertrophy in association with an upregulation of vasoactive factors and activation of nuclear factor (NF)-kappaB and activating protein-1. These effects possessed by the extract explained its inhibitory effect on diabetesinduced cardiomyocyte hypertrophy [70, 71].

The aqueous and alcoholic extracts of the Lagerstroemia speciosa possessed alpha-glucosidase inhibitory effects. The order of $\alpha$ glucosidase inhibitory effect was: aqueous extract (fruit) $\left(\mathrm{IC}_{50}=3.3\right.$ $\mu \mathrm{g} / \mathrm{ml})>$ ethanol extract (fruit) $\left(\mathrm{IC}_{50}=4.3 \mu \mathrm{g} / \mathrm{ml}\right)>$ ethanol extract (leaf) $\left(\mathrm{IC}_{50}=12.2 \mu \mathrm{g} / \mathrm{ml}\right.$ ) >aqueous extract (leaf) (IC ${ }_{50}=18.3 \mu \mathrm{g} / \mathrm{ml}$ ) [19].

The effects of extracts of Lagerstroemia speciosa on glucose transport and adipocyte differentiation were studied in 3T3-L1 cells using a radioactive assay, and the ability of extracts of Lagerstroemia speciosa to induce differentiation in preadipocytes was examined by Northern and Western blot analyses. The hot water Lagerstroemia speciosa extracts and the methanol eluent stimulated glucose uptake in 3T3-L1 adipocytes with an induction time and a dose-dependent response similar to those of insulin. There were no additive or synergistic effects between Lagerstroemia speciosa extracts and insulin on glucose uptake, and the glucose uptake activity of insulin was reduced to basal levels by adding increasing amounts of Lagerstroemia speciosa extracts. Unlike insulin, Lagerstroemia speciosa extracts did not induce adipocyte differentiation in the presence of 3-isobutyl-1-methylxanthine and dexamethasone. Lagerstroemia speciosa extracts inhibited the adipocyte differentiation induced by insulin plus 3-isobutyl-1-methylxanthine and dexamethasone of 3T3-L1 preadipocytes in a dose-dependent manner. In general, regarding the mechanisms of antidiabetic effects of Lagerstroemia speciosa. Flosin stimulated insulin-like glucose uptake, increased glucose uptake of adipocytes; and lowering blood glucose level. Reginin increased glucose uptake of adipocytes and lowering blood glucose level. Many constituents such as lagerstroemin showed insulin-mimetic activities and stimulated insulin-like glucose uptake. Corosolic acid decreased blood sugar levels within $60 \mathrm{~min}$ in human subjects, and inhibited $\alpha$-glucosidase activity. Many compounds such as 3-0-methylellagic acid, inhibited glucose transport. Lagerstroemia speciosa tea caused a $38 \%$ reduction of alpha-amylase activity. While, methanol and water extracts of Lagerstroemia speciosa reduced alpha-amylase and alpha-glucosidase activity. Both enzymes were involved in the carbohydrates digestion, their Inhibition delayed carbohydrate absorption and decreased blood sugar. All these mechanisms could be participated in the beneficial effect of Lagerstroemia speciosa in diabetes mellitus [24, 34-36, 72, 73].

The effects of corosolic acid (a pentacyclic triterpene) isolated from the leaves of the Lagerstroemia speciosa on dietary hypercholesterolemia and hepatic steatosis were assessed in KK-Ay mice, an animal model of type 2 diabetes. KK-Ay mice were fed two kinds of high cholesterol diet with or without $0.023 \%$ corosolic acid for $10 \mathrm{w}$. Corosolic acid inhibited the mean blood cholesterol level by $32 \%(\mathrm{P}<0.05)$ and the liver cholesterol content by $46 \%(\mathrm{P}<0.05)$, $10 \mathrm{w}$ after the start of dietary intake. Furthermore, corosolic acid inhibited the mean blood cholesterol level $4 \mathrm{~h}$ after the administration of a high-cholesterol cocktail in an oral cholesterolloading test, compared with that of control mice $(\mathrm{P}<0.05)[74]$.

The antiobesity effect of dietary Lagerstroemia speciosa leaves extract was studied in female mice with remarkable body weight gain. Mice were fed a control diet or test diet containing $5 \%$ of a hot-water leaves extract instead of cellulose for 12 wk. Neither group showed any changes in diet intake during the experimental period. Bodyweight gain and parametrial adipose tissue weight were lowered significantly in Lagerstroemia speciosa diet group. Blood glucose levels were not suppressed in the Lagerstroemia speciosa diet group, but hemoglobin A1C was found to be suppressed at the end of the experiment. No effects on the serum lipids were observed, but the mice fed Lagerstroemia speciosa extract showed a significant decrease (to 65\% of the control level) in total hepatic lipid contents [75].

A randomized, placebo-controlled, double-blind, parallel-group study conducted over 14 weeks (including a 2 -week run-in phase) was designed to investigate the efficacy and safety of IQP-GC-101 (a standardized extracts of Garcinia cambogia, Camellia sinensis, unroasted Coffea arabica, and Lagerstroemia speciosa) in reducing body weight and body fat mass in overweight Caucasian adults. Subjects took three IQP-GC-101 or placebo tablets, twice a day, 30 min before main meals. All subjects also adhered to a $500 \mathrm{kcal} /$ day energy deficit diet with $30 \%$ of energy from fat. After a 12 -week intervention, IQP-GC-101 resulted in a mean $( \pm$ SD) weight loss of $2.26 \pm 2.37 \mathrm{~kg}$ compared with $0.56 \pm 2.34 \mathrm{~kg}$ for placebo $(\mathrm{p}<=0.002)$. There was also significantly more reduction in body fat mass, waist circumference, and hip circumference in the IQP-GC-101 group. No serious adverse events were reported [76].

DLBS3233, a combined bioactive fraction of Cinnamomum burmanii and Lagerstroemia speciosa, possessed beneficial effects on glucose and lipid metabolism through the upregulation of insulin-signal transduction. The clinical efficacy of DLBS3233 was evaluated in type-2 diabetes mellitus subjects inadequately controlled by metformin and other oral anti-diabetic drugs. DLBS3233 was given orally at the dose of $100 \mathrm{mg}$ once daily for $12 \mathrm{w}$ of therapy in addition to their baseline oral anti-diabetic medication. After $12 \mathrm{w}$ of treatment, the HbA1c level was reduced by $0.65 \pm 1.5 \%(p=0.001)$ from baseline $(9.67 \pm 2.11 \%)$; while the $1 \mathrm{~h}$-postprandial glucose level was reduced by- $1.45 \pm 3.89 \mathrm{mmol} / \mathrm{l}(\mathrm{p}=0.021)$ from baseline $(15.29 \pm 4.49 \mathrm{mmol} / \mathrm{l})$. Insulin sensitivity, lipid profile and adiponectin level were improved to a considerable extent. DLBS3233 did not adversely affect body weight, liver, and renal function. Most adverse events observed were mild and they all had been resolved by the end of the study [77].

In other studies, after $12 \mathrm{w}$, DLBS3233 improved insulin resistance better than placebo as reflected by a reduced homeostatic modelassessed insulin resistance (HOMA-IR) $(-27.04 \% \pm 29.41 \%$ vs$4.90 \% \pm 41.27 \%, \mathrm{P}=0.013$ ). The improvement of the first-and secondphase insulin secretion was consistently greater in DLBS3233 group than placebo group $(-144.78 \pm 194.06$ vs-71.21 $\pm 157.19, P=0.022$, and-455.03 \pm 487.56 vs-269.49 $\pm 467.77, \quad \mathrm{P}=0.033$, respectively). Furthermore, DLBS3233 also significantly better improved oral disposition index than placebo. No serious hypoglycemia, edema, or cardiovascular-related adverse events were found in either groups [78].

\section{Anti-inflammatory and analgesic effects}

The anti-inflammatory activity of Lagerstroemia speciosa leaves ethyl acetate and ethanol extracts was examined using the carrageenan-induced acute inflammation and chronic formalininduced paw edema models. The ethyl acetate extract reduced the paw edema significantly in a dose-dependent manner in both acute and chronic inflammation models, while, ethanol extract did not show dose-dependent activity [55].

The analgesic actions of an aqueous ethanolic extract of Lagerstroemia speciosa was investigated using formalin-induced pain, acetic acid-induced writhing and thermal (hotplate and tail immersion) tests in rats, while, the carrageenan-induced oedema of the hind paw of rats was used to study the anti-inflammatory activities. The crude plant extract significantly increased the reaction time of hot plate and immersion tests. It decreased the writhings of acetic acid-induced abdominal contractions and lickings of formalin-induced pain. The results also showed that the aqueous ethanolic extract possessed both central and peripheral effects, this was confirmed by its effect on both phases of formalin-induced pain. The extract also significantly decreased the rat paw oedema volume at $200 \mathrm{mg} / \mathrm{kg}$ and above [79].

The analgesic potential of the flowers extracts of Lagerstroemia speciosa was assayed in mice, $16.68 \%$ inhibition of writhing was recorded for $400 \mathrm{mg} / \mathrm{kg}$ bw of the extract of Lagerstroemia speciosa. In central analgesic activity assay by tail-flick method, $48.24 \%$ elongation of the reaction time was observed after $30 \mathrm{~min}$ of administration of $400 \mathrm{mg} / \mathrm{kg}$ bw of the methanol extract of the flowers of Lagerstroemia speciosa [46].

The antinociceptive activity of chloroform extract of barks of Lagerstroemia speciosa was evaluated using acetic acid-induced gastric pain model in mice. The chloroform extract of bark of 
Lagerstroemia speciosa exhibited significant inhibition of writhing $(50.7 \%)$ at the highest dose tested $(500 \mathrm{mg} / \mathrm{kg} \mathrm{bw})$. At the lower dose of $250 \mathrm{mg}$ bark extract/kg bw, there was a decrease in the number of writhings compared to controls, but the decrease was not significant [80].

The methanolic crude extract of Lagerstroemia speciosa roots was investigated for analgesic activities using acetic acid-induced writhing inhibition method in mice. The methanolic crude extract at the dose of 200 and $400 \mathrm{mg} / \mathrm{kg}$ bw, produced $35.38 \%$ and $53.85 \%$ $(\mathrm{p}<0.001)$ inhibition of the writhing, respectively compared to standard diclofenac sodium (70.77\% inhibition) [21].

The ethanol extract of the dried fruits of Lagerstroemia speciosa also produced significant $(\mathrm{p}<0.001)$ writhing inhibition in acetic acidinduced writhing in mice at the oral dose of 250 and $500 \mathrm{mg} / \mathrm{kg}$ of bw, which was comparable to the standard drug diclofenac sodium at the dose of $25 \mathrm{mg} / \mathrm{kg}$ of bw [60].

\section{Central nervous effects}

The anticonvulsant activity of bark extracts of Lagerstroemia speciosa was studied in isoniazid and pilocarpine-induced convulsions models. By both models, $400 \mathrm{mg} / \mathrm{kg}$ of extract showed significant anticonvulsant activity by delaying the onset of convulsions [20].

In phenobarbitone-induced sleeping time test, Lagerstroemia speciosa flower extract delayed the onset of sleep (30.22 min and $38.61 \mathrm{~min}$ at 200 and $400 \mathrm{mg} / \mathrm{kg}$ bw, respectively). The extract was also found to shorten the total sleeping time (99.45 min and 107.6 $\mathrm{min}$ at 200 and $400 \mathrm{mg} / \mathrm{kg}$ bw, respectively)[46].

\section{Gastrointestinal effects}

The bark extracts of Lagerstroemia speciosa at 200 and $400 \mathrm{mg} / \mathrm{kg}$ possessed anti-gastrointestinal motility activity in mice [20]. The methanolic crude extract of Lagerstroemia speciosa roots was investigated for anti-diarrhoeal activities in an experimental animal model. The methanolic crude extract possessed anti-diarrhoeal activity and inhibited the mean number of defecation by $32.75 \%$ $(\mathrm{p}<0.01)$ and $51.72 \%(\mathrm{P}<0.001)$ at the dose of 200 and $400 \mathrm{mg} / \mathrm{kg}$ bw, respectively [21].

The ethanol extract of the dried fruits of Lagerstroemia speciosa also showed antidiarrhoeal activity on castor oil-induced diarrhoea in mice, it increased mean latent period and decreased the frequency of defecation significantly $(\mathrm{P}<0.001, \mathrm{P}<0.01)$ at the oral dose of 500 $\mathrm{mg} / \mathrm{kg}$ bw comparable to the standard drug loperamide at the dose of $50 \mathrm{mg} / \mathrm{kg}$ of bw [60].

The protective effect of methanolic extract of Lagerstroemia speciosa leaves ( 100 and $200 \mathrm{mg} / \mathrm{kg}$ bw orally for $7 \mathrm{~d}$ ) was evaluated against dextran sulfate sodium-induced ulcerative colitis in C57BL/6 mice. Both the doses of extract significantly prevented dextran sulfate sodium-induced inflammatory and ulcerative damages of the colon, reduced lipid peroxidation and also restored the levels of innate antioxidants in the colon tissue [81].

\section{Diuretic activity:}

The ethyl acetate, ethanol, methanol and water extracts $(250 \mathrm{mg} / \mathrm{kg}$ bw, orally) of Lagerstroemia speciosa were evaluated for diuretic activity in rats. The aqueous extracts showed better diuretic effect compared with other extracts. $\mathrm{Na}^{+}, \mathrm{K}^{+}$and $\mathrm{Cl}-$ excretion and $\mathrm{Na}^{+} / \mathrm{K}^{+}$ ratio was higher in aqueous extract, followed by ethanol, ethyl acetate and methanol extracts [22].

\section{Thrombolytic activity}

The thrombolytic activity of Lagerstroemia speciosa leaf methano extract was studied in 10 apparently healthy subjects (both male and female). Fraction of methanolic extract of the leaf of Lagerstroemia speciosa exhibited significant percentage of clot lysis of $25.42 \%$ compared to positive control streptokinase of $(31.06 \%)$, while the negative control saline water showed 3.81\% clot lysis [82].

The thrombolytic potential of the flowers of Lagerstroemia speciosa extracts was assayed using streptokinase as standard. the carbon tetrachloride soluble fraction induced clot lysis (64.80 $\pm 0.27 \%)$ and prevented heat-induced hemolysis $(41.90 \pm 0.10 \%)$ to the maximum extent [46].

\section{Cardiovascular effects}

The cardioprotective effect of Lagerstroemia speciosa leave extract (containing $1 \%$ corosolic acid) was evaluated in isoproterenolinduced myocardial injury in mice. Extract pretreatment augmented myocardial antioxidant status and attenuated myocardial oxidative stress. Myocardial apoptosis, as well as MMPs activities, was significantly prevented by the extract pretreatment in isoproterenolinduced myocardial injury in mice. Furthermore, extract pretreatment enhanced the nuclear protein expression of Nrf2 [83].

\section{Inhibited the TNF $\alpha$ production}

The inhibitory effect of a plant extracts on AGE-stimulated TNF $\alpha$ production of CML-stimulated cultured macrophages was investigated. Pretreatment with extracts of Lagerstroemia speciosa water chestnut, Chinese blackberry, persimmon leaf, kuma bamboo and their mixture inhibited the TNF $\alpha$ production by $14.6 \%-22.7 \%$. Cell viability was not affected by the pre-treatment with these extracts [84].

\section{Beneficial effect in skin aging}

Oxidative stress and the enhanced activation of proteolytic enzymes were part of the mechanisms of skin aging. Inhibition of these mechanisms were a promising approach to prevent skin aging. The ethanolic flowers extract of Lagerstroemia speciosa was evaluated for its inhibitory effects against hyaluronidase, elastase and tyrosinase; furthermore, the extract was investigated for its protective effects on hydrogen peroxide-induced oxidative stress in human keratinocytes. The results revealed that the antioxidant activities of the flowers extract of Lagerstroemia speciosa were equal to that of ascorbic acid. It also inhibited hyaluronidase, elastase and tyrosinase activity. In addition, the flower extract showed remarkable inhibitory potential against hyaluronidase, which was higher than that of the standard oleanolic acid. It also inhibited hydrogen peroxide-induced cell death in human keratinocytes [26].

\section{Xanthine oxidase inhibition}

The xanthine oxidase inhibition of the aqueous extracts of the leaves of Lagerstroemia speciosa was studied using a bioassay-guided fractionation technique. Two active compounds were isolated from the aqueous extracts of the Lagerstroemia speciosa leaves (valoneic acid dilactone and ellagic acid). The xanthine oxidase inhibitory effect of valoneic acid dilactone was stronger than that of allopurinol [85].

\section{Hepatoprotective effects}

The hepatoprotective activity of poorly soluble hydroxy-and polyhydroxy-organic phytomolecules rich Lagerstroemia speciosa leaves extract was studied against carbon tetrachloride-induced liver toxicity in rats. Oral administration of the extract (self micro-emulsifying formulation, at $100 \mathrm{mg} / \mathrm{kg}$ ) provided significant protection in marker enzyme, AST $(\mathrm{p}<0.001)$, ALT $(\mathrm{p}<0.001)$, ALP $(\mathrm{p}<0.001)$ and total bilirubin $(\mathrm{p}<0.001)$ comparable to that of silymarin. The extract also significantly increeased GSH, SOD and CAT contents $(\mathrm{p}<0.001)$ [86].

\section{Nephroprotective effects}

The ethyl acetate extract of leaves of Lagerstroemia speciosa was studied for nephroprotective activity in cisplatin-induced acute renal injury in Balb/C mice. The ethyl acetate extract at dose levels of 50 and $250 \mathrm{mg} / \mathrm{kg}$ showed a dose-dependent reduction in cisplatin-induced elevations in urea and creatinine concentrations. It also prevented the cisplatin-induced decline of the renal antioxidant enzymes superoxide dismutase, catalase, glutathione peroxidase, and reduced glutathione [87].

Ginseng and Lagerstroemia speciosa leaf extracts, individually or in combination at a dose of $150 \mathrm{mg} / \mathrm{kg}$ bw/day for $15 \mathrm{~d}$ exhibited protective effects on fluoride toxicated STZ induced nephrotoxicity in mice [88]. 


\section{Side effects and safety}

The crude ethanol extract is non-toxic in rats, it was well tolerated at a concentration of $500,1000,2000$, and $3000 \mathrm{mg} / \mathrm{kg}$, No biochemical and histological changes were recorded [89]. In acute toxicity study, no mortality or toxic reaction was recorded in rats after administration the methanolic crude extract of Lagerstroemia speciosa roots (200, 400, 800, 1600 and $3200 \mathrm{mg} / \mathrm{kg}$, orally) [21].

There were no side effects in human, with the using of the recommended dosages (8-48 mg/day). However, higher doses associated with lowered blood glucose levels, headache, dizziness, and fatigue [90].

\section{CONCLUSION}

The current review discussed the pharmacological effects of Lagerstroemia speciosa which included antimicrobial, antioxidant, anticancer, antidiabetic, hypolipidemic, antiobesity, anti-inflammatory, analgesic, gastrointestinal, diuretic, thrombolytic, cardiovascular, central nervous, inhibition of TNF $\alpha$ production, xanthine oxidase inhibitition, hepatoprotective and nephroprotective effects. The review also highlighted the chemical constituents, toxicity and the recommended doses of Lagerstroemia speciosa as a promising medicinal plant for therapeutic purposes as a result of effectiveness and safety.

\section{ACKNOWLEDGMENT}

I acknowledged the dean of Thi Qar College of medicine for his scientific support.

\section{AUTHORS CONTRIBUTIONS}

All the author have contributed equally

\section{CONFLICTS OF INTERESTS}

There is no conflicts of interest. I am, alone responsible for the content and writing of this article.

\section{REFERENCES}

1. Al-Snafi AE. Chemical constituents and pharmacological activities of milfoil (Achillea santolina)-a review. Int J Pharm Tech Res 2013;5:1373-7.

2. Al-Snafi AE. The pharmaceutical importance of Althaea officinalis and Althaea rosea: a review. Int J Pharm Tech Res 2013;5:1387-5.

3. Al-Snafi AE. The pharmacological importance of Anethum graveolens-a review. Int J Pharm Pharm Sci 2014;6:11-3.

4. Al-Snafi AE. The pharmacology of Anchusa italica and Anchusa strigosa-A review. Int J Pharm Pharm Sci 2014;6:7-10.

5. Al-Snafi AE. Pharmacological and therapeutic importance of Hibiscus sabdariffa-A review. Int J Pharm Res 2018;10:451-75.

6. Al-Snafi AE. Immunological effects of medicinal plants: a review (part 2). Immunol Endocr Metab Agents Med Chem 2016;16:100-21.

7. The Plant List, Lagerstroemia speciosa. Available from: http://www.theplantlist.org/tpl/record/kew-2353907. [Last accessed in 10 Apr 2019]

8. IT IS, Lagerstroemia speciosa. Available from: https://www.itis.gov/servlet/SingleRpt/SingleRpt?search_topi $c=$ TSNandsearch_value $=27111$ \#null. [Last accessed in $10 \mathrm{Apr}$ 2019].

9. Philippine medicinal plants, Lagerstroemia speciosa. Available from: http://www.stuartxchange.org/Banaba.html [Last accessed in 10 Apr 2019]

10. US National Plant Germplasm System, Lagerstroemia speciosa (L.) Pers. Available from: https://npgsweb.arsgrin.gov/gringlobal/taxonomydetail.aspx?id=21399 [Last accessed in 10 Apr 2019].

11. Takano J. Lagerstroemia Speciosa L. (Banaba or Queen's Flower)-Wonders of Botanical Herbs, Pyroenergen; 2013. Available from: http://www.pyroenergen.com/other products/banaba-plant.htm [Last accessed in $10 \mathrm{Apr} 2019$ ]

12. Castro IR. A guide to families of common flowering plants in the Philippines. Quezon City, The University of the Philippines Press; 2006. p. 106.
13. McMinn H, Maino E, Shepherd HW. An illustrated manual of pacific coast trees. Berkerly, University of Calfornia Press; 1980. p. 297.

14. Tropilab In, Lagerstroemia speciosa. Available from: https://tropilab.com/queen-flow.html [Last accessed in $10 \mathrm{Apr}$ 2019].

15. Vardhana R. Direct uses of medicinal plants and their identification. New Delhi, Sarup and Sons; 2008. p. 203.

16. Wei D. Philippine medicinal plants-banaba, stuart xchange; 2003. http://www.stuartxchange.com/Banaba.html [Last accessed in 10 Apr 2019]

17. Vardhana R. Direct uses of medicinal plants and their identification. New Delhi, Sarup and Sons; 2008. p. 203.

18. Thitikornpong $\mathrm{W}$, Phadungcharoen $\mathrm{T}$, Sukrong $\mathrm{S}$. Pharmacognostic evaluations of Lagerstroemia speciosa leaves. J Med Plants Res 2011;5:1330-7.

19. Myint PP, Soe MT, Hlaing HH. A study of phytoconstituents, $\alpha-$ glucosidase inhibitory effect and antioxidant activity of Lagerstroemia speciosa L. Leaf and fruit. J Pharmacogn Phytochem 2017;6:528-33.

20. Bhowmik NR, Mogha MR, Barua S. Characterization of phytoconstituents and evaluation of gastrointestinal motility and anticonvulsant activities of Lagerstroemia speciosa linn (bark). World J Pharm Sci 2016;4:309-13.

21. Hussain F, Ganguly A, Hossain MS, Rahman SMA. Analgesic and anti-diarrhoeal activities of Lagerstroemia speciosa roots in experimental animal model. Dhaka Univ J Pharm Sci 2014;13:57-62.

22. Thambi PT, Chacko SM, Chungath JI. Studies on the diuretic effect of Lagerstroemia speciosa Linn. leaf extracts in normal rats. Res J Pharm Biol Chem Sci 2013;4:1-9.

23. Bhaumik A, Ramu B, Rahman F, Basheer S, Mastanaiah J. The bioactive compounds of fruit of Lagerstroemia speciosa $L$. act as potential antimicrobial agent. Int J Pharm Res Health Sci 2014;2:476-80.

24. Hou W, Li Y, Zhang Q, Wei X, Peng A, Chen L. Triterpene acids isolated from Lagerstroemia speciosa leaves as $\alpha$-glucosidase inhibitors. Phytother Res 2009;23:614-8.

25. Jayakumar KS, Sajan JS, Aswati Nair R, Padmesh Pillai P, Deepu $\mathrm{S}$, Padmaja R, Agarwal A, et al. Corosolic acid content and SSR markers in Lagerstroemia speciosa (L.) pers: a comparative analysis among populations across the Southern Western Ghats of India. Phytochemistry 2014;106:94-103.

26. Kolakul P, Sripanidkulchai B. Phytochemicals and anti-aging potentials of the extracts from Lagerstroemia speciosa and Lagerstroemia floribunda. Ind Crops Prod 2017;109:707-16.

27. Choi J, Cho JY, Choi SJ, Jeon H, Kim YD, Htwe KM, et al. Two new phenolic glucosides from Lagerstroemia speciosa. Molecules 2015;20:4483-91.

28. Kesavanarayanan KS, Sathiya S, Ranju V, Sunil AG, Ilavarasan $\mathrm{R}$, Saravana Babu C, et al. In vitro cytotoxic, antioxidative and alpha-glucosidase inhibitory potential of a herbal mixture comprised of Allium sativum and Lagerstroemia speciosa. Eur Rev Med Pharmacol Sci 2012;16(Suppl 3):58-68.

29. Ragasa CY, Ngo HT, Rideout JA. Terpenoids and sterols from Lagerstroemia speciosa. J Asian Nat Prod Res 2005;7:7-12.

30. Bai N, He K, Roller M, Zheng B, Chen X, Shao Z, et al. Active compounds from Lagerstroemia speciosa, insulin-like glucose uptake-stimulatory/inhibitory and adipocyte differentiationinhibitory activities in 3T3-L1 cells. J Agric Food Chem 2008;56:11668-74.

31. Rahman SM, Pervin S, Quader A, Hossain MA. Phytochemical studies of the petroleum ether extract of the leaves of Lagerstroemia speciosa Linn. Indo J Chem 2009;9:470-3.

32. Takahashi M, Ueda J, Sasaki JI. The components of the plants of Lagerstroemia genus. IV. On the presence of the ellagic acid derivatives from the leaves of Lagerstroemia subcostata Koehne. and $L$ speciosa (L.) Pers. and the synthesis of 3,4-di-omethylellagic acid. Yakugaku Zasshi 1977;97:880-2.

33. Takahashi M, Osawa K, Ueda J, Yamamoto F, Tsai CT. The components of the plants of Lagerstroemia genus. III. On the structure of the new tannin (lagertannin) from the leaves of Lagerstroemia speciosa (L.) pers. Yakugaku Zasshi 1976;96:984-7. 
34. Xu YM, Sakai T, Tanaka T, Nonaka G, Nishioka I. Tannins and related compounds CVI preparation of amino alditol derivatives of hydrolysable tannins having $\alpha$-and $\beta$-glucopyranose cores, and its application to the structure elucidation of new tannins reginins $\mathrm{A}$ and $\mathrm{B}$ and flosin $\mathrm{A}$ isolated from Lagerstroemia flosreginae retz. Chem Pharm Bull 1991;39:639-46.

35. Xu YM, Tanaka T, Nonaka G, Nishioka I. Tannins and related compounds CVII structure elucidation of three new monomeric and dimeric ellagitannins flosin B reginins C and D isolated from Lagerstroemia flosreginae retz. Chem Pharm Bull 1991;39:647-50.

36. Tanaka T, Tong HH, Xu YM, Ishimaru K, Nonaka G, Nishioka I. Tannins and related compounds. CXVII Isolation and characterization of three new ellagitannins lagerstannins A, B and C having a gluconic acid core from Lagerstroemia speciosa (L.). Pers Chem Pharm Bull 1992;40:2975-80.

37. Okada Y, Omae A, Okuyama T. A new triterpenoid isolated from Lagerstronemia speciosa (L.) pers. Chem Pharm Bull (Tokyo) 2003;51:452-4.

38. Jehan CM, Daulatabad D, Mirajkar A. A keto fatty acid from Lagerstroemia speciosa seed oil. Phytochemistry 1990;29:2323-4.

39. Sinhababu A, Das S, Laskar S, Thakur S, Sen SK. Characterization and identification of antibacterial components in extracts of seeds from Lagerstroemia speciosa. Adv Food Sci 1999;21:19-22.

40. Oloyede GK, Olandosu IA, Oloyade OO. Chemical composition and cytotoxic effect of Largerstroemia speciosa fruits essential oils. Int J Biol Chem Sci 2010;4:1851-4.

41. Thambi PT, Sabu MC, Chungath JI. Essential oils composition and cytotoxic effect of Lagerstroemia speciosa linn flowers. J Pharmacol Toxicol Studies 2016;4:1-5.

42. Sinhababu A, Basak B, Laskar S, Chakrabarty D, Sen SK. Effect of different fractions of petroleum ether (60-80 degrees) extracts of the seeds of Lagerstroemia speciosa (Linn ex Murray) pers on some microorganisms. Hind Antibiot Bull 1994;36:39-45.

43. Nasrin F, Ahmad S, Kamrunnahar. Evaluation of antimicrobial, lxidant and cytotoxic activities of methanolic extracts of Lagerstroemia speciosa leaves and barks. J Appl Pharm Sci 2012;2:142-7.

44. Saraswathi VS, Kamarudheen N, Bhaskara Rao KV, Santhakumar K. Biofilm inhibition formation of clinical strains of Pseudomonas aeruginosa mutans, the photocatalytic activity of azo dye and GCMS analysis of leaves of Lagerstroemia speciosa. J Photochem Photobiol B 2017;169:148-60.

45. Ambujakshi HR, Surendra V, Haribabu T, Goli D. Antibacterial activity of leaves of Lagerstroemia speciosa (L) pers. J Pharm Res 2009;2:1028.

46. Sharmin T, Rahman MS, Mohammadi H. Investigation of biological activities of the flowers of Lagerstroemia speciosa, the Jarul flower of Bangladesh. BMC Complement Altern Med 2018;18:231.

47. Laruan LM, Balangcod TD, Balangcod K, Patacsil M. Phytochemical and antibacterial study of Lagerstroemia speciosa and its ethnomedicinal importance to indigenous communities of Benguet province, philippines. Acta Horticulturae 2014;1023:137-42.

48. Lai KH, Darah I, Wong CT, Afifah S, Lim SH. In vitro antibacterial activity and cytotoxicity of Lagerstroemia speciosa bark extract. Indian J Pharm Sci 2016;78:273-7.

49. Singh BN, Singh HB, Singh A, Singh BR, Mishra A, Nautiyal CS. Lagerstroemia speciosa fruit extract modulates quorum sensing-controlled virulence factor production and biofilm formation in Pseudomonas aeruginosa. Microbiology 2012;158:529-38.

50. Choi HJ, Bae EY, Song JH, Baek SH, Kwon DH. Inhibitory effects of orobol 7-O-D-glucoside from banaba (Lagerstroemia speciosa L.) on human rhinoviruses replication. Lett Appl Microbiol 2010;51:1-5.

51. Song JH, Park KS, Kwon DH, Choi HJ. Anti-human rhinovirus 2 activity and mode of action of quercetin-7-glucoside from Lagerstroemia speciosa. J Med Food 2013;16:274-79.

52. Nutan, Modi M, Goel T, Das T, Malik S, Suri S, et al. Ellagic acid and gallic acid from Lagerstroemia speciosa L inhibit HIV-1 infection through inhibition of HIV-1 protease and reverse transcriptase activity. Indian J Med Res 2013;137:540-8.

53. Park SW, Kwon MJ, Yoo JY, Choi HJ, Ahn YJ. Antiviral activity and possible mode of action of ellagic acid identified in Lagerstroemia speciosa leaves toward human rhinoviruses. BMC Complement Altern Med 2014;14:171.

54. Anil P, Manish S, Garvendra SR, Vijay B, Tarachand K. In vitro antioxidant studies of Lagerstroemia speciosa leaves. Phcog Net 2010;2:357-60.

55. Priya TT, Sabu MC, Jolly CI. Free radical scavenging and antiinflammatory properties of Lagerstroemia speciosa (L). Inflammopharmacology 2008;16:182-7.

56. Unno T, Sakane I, Masumizu T, Kohno M, Kakuda T. Antioxidative activity of water extracts of Lagerstroemia speciosa leaves. Biosci Biotechnol Biochem 1997;61:1772-4.

57. Song JL, Zhao X, Wang Q, Zhang T. Protective effects of Lagerstroemia speciosa on 3-morpholinosydnonimine (SIN-1)induced oxidative stress in HIT-T15 pancreatic $\beta$ cells. Mol Med Rep 2013;7:1607-12.

58. Sung B, Kang YJ, Kim DH, Hwang SY, Lee Y, Kim M, et al. Corosolic acid induces apoptotic cell death in HCT116 human colon cancer cells through a caspase-dependent pathway. Int J Mol Med 2014;33:943-9.

59. Saraswathi VS, Saravanan D, Santhakumar K. Isolation of quercetin from the methanolic extract of Lagerstroemia speciosa by HPLC technique, its cytotoxicity against MCF-7 cells and photocatalytic activity. J Photochem Photobiol B 2017; 171:20-6.

60. Rahman A, Uddin N, Hasanuzzaman M, Rahman AA. Antinociceptive antidiarrhoeal and cytotoxic activities of Lagerstroemia speciosa (L.) pers. Pharmacologyonline 2011;1:604-12.

61. Klein G, Kim J, Himmeldirk K, Cao Y, Chen X. Antidiabetes and anti-obesity activity of Lagerstroemia speciosa. Evid Based Complement Alternat Med 2007;4:401-7.

62. Judy WV, Hari SP, Stogsdill WW, Judy JS, Naguib YM, Passwater R. Antidiabetic activity of a standardized extract (Glucosol) from Lagerstroemia speciosa leaves in type II diabetics. A dose-dependence study. J Ethnopharmacol 2003;87:115-7.

63. Saumya SM, Basha PM. Antioxidant effect of Lagerstroemia speciosa pers (banaba) leaf extract in streptozotocin-induced diabetic mice. Indian J Exp Biol 2011;49:125-31.

64. Thuppia A, Rabintossaporn P, Saenthaweesuk S, Ingkaninan K, Sireeratawong $\mathrm{S}$. The hypoglycemic effect of water extract from leaves of Lagerstroemia speciosa L in streptozotocin-induced diabetic rats. Songklanakarin J Sci Technol 2009;31:133-7.

65. Tanquilut NC, Tanquilut MRC, Estacio MAC. Hypoglycemic effect of Lagerstroemia speciosa (L) pers on alloxan-induced diabetic mice. J Med Plants Res 2009;3:1066-71.

66. Kakuda T, Sakane I, Takihara T, Ozaki Y, Takeuchi H, Kuroyanagi M. Hypoglycemic effect of extracts from Lagerstroemia speciosa L leaves in genetically diabetic KKAY mice. Biosci Biotechnol Biochem 1996;60:204-8.

67. Hayashi T, Maruyama H, Kasai R, Hattori K, Takasuga S, Hazeki 0 , et al. Ellagitannins from Lagerstroemia speciosa as activators of glucose transport in fat cells. Planta Med 2002;68:173-5.

68. Ortiz MG. Effect of banaba (Lagerstroemia speciosa) on metabolic syndrome, insulin secretion and insulin sensitivity. University of Guadalajara; 2017. Available from: https://clinicaltrials.gov/ct2/show/NCT02767869 [Last accessed in 10 Apr 2019].

69. Bhokare KH, Upaganlawar AB. Neuroprotective effects of Lagerstroemia speciosa L. extract (Banaba leaf extract) in streptozotocine induced painful diabetic neuropathy in laboratory rats. Pharmacologia 2016;7:9-15.

70. Lampronti I, Khan MT, Bianchi N. Bangladeshi medicinal plant extracts inhibiting molecular interactions between nuclear factors and target DNA sequences mimicking NF-kappaB binding sites. Med Chem 2005;1:327-33.

71. Ichikawa $\mathrm{H}$, Yagi $\mathrm{H}$, Tanaka $\mathrm{T}$, Cyong JC, Masaki $\mathrm{T}$. Lagerstroemia speciosa extract inhibit TNF-induced activation of nuclear factor-kappaB in rat cardiomyocyte H9c2 cells. J Ethnopharmacol 2010;128:254-6. 
72. Park C, Banaba LJ. The natural remedy as an antidiabetic drug. Biomed Res 2011;22:127-31.

73. Liu F, Kim J, Li Y, Liu X, Li J, Chen X. An extract of Lagerstroemia speciosa $\mathrm{L}$ has insulin-like glucose uptake-stimulatory and adipocyte differentiation-inhibitory activities in 3T3-L1 cells. J Nutr 2001;131:2242-7.

74. Takagi S, Miura T, Ishihara E, Ishida T, Chinzei Y. Effect of corosolic acid on dietary hypercholesterolemia and hepatic steatosis in KK-Ay diabetic mice. Biomed Res 2010;31:213-8.

75. Suzuki Y, Unno T, Ushitani M, Hayashi K, Kakuda T. Antiobesity activity of extracts from Lagerstroemia speciosa L. leaves on female KK-Ay mice. J Nutr Sci Vitaminol (Tokyo) 1999;45:791-5.

76. Chong P, Beah Z, Grube B, Riede L. IQP-GC-101 reduces body weight and body fat mass: a randomized, double-blind, placebo-controlled study. Phytother Res 2014;28:1520-6.

77. Tjokroprawiro A, Murtiwi S, Tjandrawinata RR. DLBS3233, a combined bioactive fraction of Cinnamomum burmanii and Lagerstroemia speciosa, in type-2 diabetes mellitus patients inadequately controlled by metformin and other oral antidiabetic agents. J Complement Integr Med 2016;13:413-20.

78. Manaf A, Tjandrawinata RR, Malinda D. Insulin sensitizer in prediabetes: a clinical study with DLBS3233, a combined bioactive fraction of Cinnamomum burmanii and Lagerstroemia speciosa. Drug Des Dev Ther 2016;10:1279-89.

79. Gupta A, Agrawal VK, Rao CV. Exploration of analgesic and antiinflammatory potential of Lagerstroemia speciosa. J Appl Pharm Sci 2017;7:156-61.

80. Morshed A, Hossain H, Shakil S, Nahar K, Rahman S, Ferdausi D, et al. Evaluation of the antinociceptive activity of two Bangladeshi medicinal plants, Kalanchoe pinnata (Lam.) pers and Lagerstroemia speciosa (L.) pers. Adv Nat Appl Sci 2010;4:193-7.

81. Chaudhary G, Mahajan UB, Goyal SN, Ojha S, Patil CR, Subramanya SB. Protective effect of Lagerstroemia speciosa against dextran sulfate sodium-induced ulcerative colitis in C57BL/6 mice. Am J Transl Res 2017;9:1792-800.

82. Chowdhury AR, Islam R, Muktadir AG. Thrombolytic activity of Lagerstroemia speciosa leaves. Discovery Phytomed 2017;4:41-5.

83. Sahu BD, Kuncha M, Rachamalla SS, Sistla R. Lagerstroemia speciosa L. attenuates apoptosis in isoproterenol-induced cardiotoxic mice by inhibiting oxidative stress: possible role of Nrf2/HO-1. Cardiovasc Toxicol 2015;15:10-22.

84. Sato K, Yagi M, Takabe W, Yonei Y. Inhibitory effect of plant extract on tumor necrosis factor- $\alpha$ formation from carboxymethyl lysine stimulated macrophages. Glycative Stress Res 2015;2:191-6.

85. Unno T, Sugimoto A, Kakuda T. Xanthine oxidase inhibitors from the leaves of Lagerstroemia speciosa (L.) pers. J Ethnopharmacol 2004;93:391-5.

86. Amresh G, Agarwal VK, Rao CV. Self micro emulsifying formulation of Lagerstroemia speciosa against chemically induced hepatotoxicity. J Tradit Complement Med 2017;8:164-9.

87. Priya TT, Sabu MC, Jolly CI. Amelioration of cisplatin induced nephrotoxicity in mice by an ethyl acetate extract of Lagerstroemia speciosa (L). J Basic Clin Physiol Pharmacol 2007;18:289-98.

88. Basha MP, Saumya SM. Influence of fluoride on streptozotocininduced diabetic nephrotoxicity in mice: protective role of Asian ginseng (Panax ginseng) and banaba (Lagerstroemia speciosa) on mitochondrial oxidative stress. Indian J Med Res 2013;137:370-9.

89. Azad AK, Rahman MK, Sunzida NK. Acute oral toxicity study on Malaysian traditional herb: Lagerstroemia speciosa L. (Banaba). J Pharmacogn Phytochem 2015;4:228-32.

90. Talbott SM, Hughes K. The Health professional's guide to dietary supplements. Baltimore, Lippincott Williams, and Wilkins; 2007. p. 409-10. 